\title{
Loyalty of Paratransit Users in the Era of Competition with Ride Sourcing
}

\author{
Tri Basuki Joewono ${ }^{1, *(1)}$, Ariel Matthew ${ }^{1}$ and Muhamad Rizki ${ }^{2}$ \\ 1 Department of Civil Engineering, Faculty of Engineering, Universitas Katolik Parahyangan, \\ Bandung 40141, Indonesia; ariel.matthew2007@gmail.com \\ 2 Department of Civil Engineering, Institut Teknologi Nasional Bandung, Bandung 40124, Indonesia; \\ muhamadrizki1404@itenas.ac.id \\ * Correspondence: vftribas@unpar.ac.id; Tel.: +62-22-203-2655
}

Citation: Joewono, T.B.; Matthew, A.; Rizki, M. Loyalty of Paratransit Users in the Era of Competition with Ride Sourcing. Sustainability 2021, 13, 12719. https://doi.org/10.3390/ su132212719

Academic Editor: Elżbieta Macioszek

Received: 25 October 2021

Accepted: 15 November 2021

Published: 17 November 2021

Publisher's Note: MDPI stays neutral with regard to jurisdictional claims in published maps and institutional affiliations.

Copyright: (c) 2021 by the authors. Licensee MDPI, Basel, Switzerland. This article is an open access article distributed under the terms and conditions of the Creative Commons Attribution (CC BY) license (https:// creativecommons.org/licenses/by/ $4.0 /)$.

\begin{abstract}
As a mode serving urban mobility in developing countries, paratransit is experiencing competition with the fast and massive growth of ride sourcing. This study aims to investigate the loyalty of paratransit users in Bandung, Indonesia, in the era of competition with ride sourcing. Data collected by questionnaires and distributed to 400 paratransit users in Bandung were analysed using hierarchical structural equation modelling. The analysis shows that satisfaction is positively influenced by service quality variables. Though there is less satisfaction compared to the previous decade, satisfaction with the service still has a positive influence on total satisfaction with the mode. It can also be concluded that loyalty is positively influenced by satisfaction. Satisfaction with the image and the unique characteristics of paratransit retains passengers' intentions toward loyalty in the future, including current personal characteristics (i.e., age, income, occupation) and travel characteristics (i.e., fare, vehicle ownership) of passengers. This study warns of the high probability of mode-changing behaviour from paratransit to another mode.
\end{abstract}

Keywords: paratransit; loyalty; ride sourcing; competition

\section{Introduction}

With the advancement of information and communication technology (ICT) and the widespread use of smartphone software, ride sourcing has become a major influence in the transportation industry. Ride sourcing uses mobile application software to connect potential passengers with informal drivers [1]. Ride sourcing provides a reliable, lower cost, on-demand and door-to-door transportation service [2]. With such advantages owned by ride sourcing, Uber took six years to reach the one-billion-trip milestone in 2015, but only six additional months to reach two billion trips [3]. Studies show that high demand for ride sourcing can contribute to mitigating congestion, reducing car ownership, and stabilizing car ownership growth over the long term [4,5]. In Southeast Asia (SEA), ride sourcing has become significant in the economy, its value approaching 13 billion USD, with 40 million active users in 2019 [6]. Ride sourcing in Indonesia was first launched in 2010 by Gojek [7]; it subsequently bloomed from 3000 to 10,000 users a day in 2015 [8] and had accumulated 5 billion kilometres of travel in 2019 [9]. Besides Gojek, other operators such as Grab compete in the Indonesian market.

On the other hand, there is an existing flexible urban transport service, known as paratransit. The term 'paratransit' in developing countries encompasses a variety of transport modes and service facilities, falling between conventional transport services and private automobiles [10]. Paratransit is not as formal and massive as mass transit [11,12]. Paratransit serves urban mobility in many developing countries under different local names [11], such as jeepney in the Philippines, tuk-tuk and songtaew in Thailand, dolmush in Istanbul, and mammy wagons (converted trucks) and matatu (converted vans) in some African countries. In Indonesia, paratransit is known as angkutan kota, abbreviated to 
Angkot as its generic local name: it refers to various type of car, van and minibus with 12-14 seat capacity [11]. Paratransit is a type of indigenous transport that exists in many developing countries [13]. Paratransit thrives because it fulfils the transportation need of middle-to-lower class citizens, is flexible in terms of mobility, and fills the gap between private transport and public transport (PT) [14]. Paratransit also offers job opportunities to reduce unemployment [15]. Most developing countries with middle-to-low incomes depend on paratransit as a reliable transportation mode [16]. Paratransit, in this case, is different from the paratransit for elderly or disabled persons that is available in the US.

In the era of digitalization, the rapid growth of ride sourcing can be complementary to public transport or substitutive of it [17]. Ride-sourcing services have a role in supporting the public transport system in developing countries $[18,19]$. Other studies have argued that ride sourcing complements secondary and/or feeder systems in developed countries $[20,21]$. Besides the positive impact on public transport, ride sourcing may compete with paratransit and public transport in serving urban mobility needs. Rizki et al. [22] found that younger travellers substitute ride sourcing for public transport. Irawan et al. [23] confirmed the superiority of motorcycle-based ride sourcing in Yogyakarta, Indonesia, compared with the existing bus service. Competition between ride sourcing and public transport is more likely to happen when travel time by public transport is disproportionately longer than by ride sourcing [24]. The main impact of ride sourcing on public transport is the shift in public transport usage, even replacing it entirely. In Tehran, although there is a good public transport system, the majority of users depend on ride sourcing as their transportation mode [25]. Research has found that ride sourcing pulls people away from public buses and light rail but complements heavy rail [26]. Rayle et al. [17] also found that half of ride-sourcing trips replace public transport and driving. In the case of paratransit in Indonesia, paratransit is also affected by the growth of ride sourcing, decreasing the willingness to ride, reducing the income of paratransit drivers in Kediri, Indonesia [27], reducing the paratransit fleet [28], and reducing the attraction of this service over ride sourcing [29].

This opens a question regarding the future of paratransit as a mode of urban transport in developing countries. Even though paratransit has many advantages, its popularity is clearly threatened by the growth of ride sourcing. In other words, the sustainability of paratransit depends largely on the loyalty of current passengers. Therefore, the loyalty of passengers becomes critical to ensure the survival of paratransit. Sustaining and improving passengers' loyalty is accepted as an effective strategy for the development of public transport [30] and increasing ridership [31]. Analysis of current passenger loyalty may also reveal factors that influence PT competitiveness [32]. Study regarding passengers' loyalty is also useful for transit agencies at a time when passengers show different levels of satisfaction and complaint about the service [33]. Many loyalty studies have been conducted to find a way to retain current passengers and to attract new ones-for example, the studies by Van Lierop et al. [34], Shiftan et al. [35], Vicente et al. [36] and Fu et al. [37]. Most of the studies employ data from developed countries, while limited studies have been conducted using empirical data from developing countries. Studies are more limited when it comes to investigating loyalty to the paratransit service: a small number can be mentioned, such as studies in Indonesia, Vietnam, the Philippines, or India [11,12,38-44].

This study investigates how loyal current passengers are to paratransit. It follows the idea that passengers' loyalty is important to retain current passengers of the mode [30-44]. The aim of this study is to examine the loyalty of paratransit users in the era of digitalization with the existence of ride sourcing. Data from questionnaires distributed to paratransit users in Bandung, Indonesia are analysed using hierarchical structural equation modelling. The contributions of this study are threefold. Firstly, the study fills the gap in discussion about loyalty to paratransit services in a developing country. Secondly, it is expected to enrich knowledge about the future of informal transport in the era of competition with online transportation. Thirdly, this study will provide knowledge about the impact of ride sourcing on existing urban transport in a developing country. 
After this introduction, loyalty to public transport in the era of competition is discussed in the second section. The third part presents the data collection and description, including the proposed model. The fourth part of this article describes the model estimation. This is followed by a discussion and conclusion section.

\section{Loyalty of Public Transport Users}

Loyalty to public transport is a customer's intention to use the service in the future based on previous experience [45]. In the field of marketing, customer loyalty is defined as "a deeply held commitment to repurchase or re-patronize a preferred product or service in the future" [46]. Loyalty needs an operational definition to be represented as a tangible and functional construct [31]. Though the literature does not offer a universal way of defining customer loyalty operationally [31], three components are used to explain it, namely intention to repurchase or reuse, likelihood of recommending to others, and overall customer satisfaction [47]. Operationally, loyalty is influenced by satisfaction. Users of public transport who are satisfied, intend to continue to use, and are willing to recommend the service to others will demonstrate loyalty towards public transport $[38,45,47,48]$. Loyalty can be expressed in many ways, from continuous behaviour to purchasing a product or using a service, consumer attitude and emotions towards a service on an ongoing basis, intended future usage, or willingness to recommend [49-51].

Passengers' loyalty can be assessed on both the attitudinal and the behavioural level [30,31], where passengers could be falsely characterized as loyal by attaching a relatively low level of preference or attitude to public transit (PT) users who have high behavioural patronage [31]. These two aspects form a customer's total loyalty [52]. The behavioural level is the surface level aspect of loyalty that is indicated by someone's repetitive selection of a certain brand over the competition [53]. The attitudinal aspect refers to service selection decisions based on a combination of facts and emotions, developing an emotional attachment and trust in a product or service [31].

Studies exploring the cause of customers' loyalty to a particular service mainly employ standard satisfaction-loyalty theory [54]. In this theory, perceived quality and customer satisfaction significantly contribute to loyalty development and enhancement, while satisfaction is an important factor partially/completely mediating the impact of service quality on loyalty [37].

Many studies have focused on how to increase the loyalty of PT users. Customers' beliefs about a product/service (expectation) and the extent of consistency of the actual experience with the initial expectation (confirmation) have been found to be important in customer loyalty and satisfaction [37]. Loyalty is also affected by the four phenomena of loyalty attitude, hedonic value, utilitarian value, and satisfaction [35]. Fu [33] investigated the interaction of perceived service quality, perceived value, corporate image, satisfaction, and complaints in terms of the influence on passengers' loyalty to PT. Van Lierop et al. [34] conducted an analysis of the causes of satisfaction and loyalty in PT, while Imaz et al. [55] focused on the role of service attributes, satisfaction, trip characteristics, and socioeconomic and psychological attributes in PT loyalty. Studies have shown that some determinant attributes of PT service influence satisfaction and loyalty, such as on-board experience, service delivery, waiting conditions, customer service, cost, quality of transfers, and image [34].

Several issues have also been found to influence factors in loyalty in PT-for example, preferential (the experience of riding the busway service), moral (pro-environmental concerns), and constraint considerations (cost of busway and car use) [56]; PT cost and the attractiveness of cars [32]; critical incidents or unwanted events [57]; and environmental sustainability [36].

In the era of competition between PT, private cars and online transportation, studies on the competitiveness of PT are crucial. Understanding the indicators of PT's competitiveness can motivate individuals to change to use PT for personal mobility [58]. Sumaedi et al. [59] investigated the simultaneous effect of perceived value, image, perceived ease of use, and perceived usefulness on passengers' satisfaction in the context of the competitiveness of 
PT. Current passenger loyalty is also employed in the analysis of PT competitiveness [32], where PT service quality is found to be the most important factor influencing a passenger's willingness to remain loyal. The idea of using loyalty as a proxy to investigate competitiveness is rooted in the operational definition of loyalty, namely intention to repurchase or reuse, likelihood of recommending to others, and overall customer satisfaction [31,47]. Thus, knowledge about passenger loyalty will provide knowledge about the future of the service-in this case, the retention of current PT passengers [30,32,34,60].

The concept of loyalty is also employed to investigate the future of paratransit. While the number of studies is quite limited, some studies can be mentioned. The loyalty of paratransit passengers in Indonesia has been investigated by Joewono and Kubota [11,12,38,39] and Tarigan et al. [40] using empirical data from Bandung, while Nasrullah et al. [44] employed data from Jabodetabek. Loyalty of paratransit users in Phnom Penh, Vietnam, has been investigated by Phun et al. [41]. Loyalty of paratransit users in Metro Manila has been investigated by Tiglao et al. [42]. Loyalty to paratransit services in India has been investigated by Sharma et al. [43]. It is interesting to note that the literature documents limited studies on loyalty to paratransit services, but studies about loyalty to ride sourcing have been growing in number. Some studies can be mentioned-for example, the study by Nguyen-Phuoc et al. [61] regarding the influence of perceived risk, passenger satisfaction, and loyalty towards ride-sourcing services. Su et al. [62] investigated perceived safety, involvement, and perceived service quality in relation to loyalty intention among ride-sourcing passengers. Rizki et al. [7] investigated the effects of on-journey, before-journey, and multi-tasking advantages when using ride sourcing in order to know its future usage. Wenzel et al. [63] estimated that the net effect of ride sourcing on energy use increased compared to baseline before the existence of ride sourcing. Yang et al. [64] investigated the effect of a reward account on loyalty to a ride-sourcing service. Documented studies provide evidence that ride sourcing has a positive and negative effect on PT in the form of substitution or a complementary effect [17]. The more crucial finding is the substitution effect of ride sourcing on PT services. Evidence from previous studies has shown the threat posed to PT by ride sourcing in many places in the world, such as Tehran [25], the US [26], Zurich [65], and Amsterdam [66].

From the literature as described, the important role of this study regarding loyalty in maintaining the sustainability of PT services is emphasized. As a matter of fact, study of loyalty to paratransit is quite limited. This indicates a knowledge gap regarding the future of this flexible mode of urban transport, especially in developing countries. The challenge becomes greater as competition from the massive growth of ride sourcing has come with unprecedented evidence. Thus, this study will contribute to filling the gap regarding the future of paratransit in a developing country in the era of competition with online transportation.

Based on the described literature, the hypotheses of this study are as follows.

Hypothesis 1 (H1). Satisfaction with paratransit is influenced by personal, travel, and mode and service characteristics (i.e., availability, accessibility, reliability, information, customer service, comfort, safety and security, fare, and environment).

Hypothesis 2 (H2). Loyalty to paratransit is explained by satisfaction with paratransit as well as drivers' job satisfaction and personal, travel, and mode and service characteristics (i.e., availability, accessibility, reliability, information, customer service, comfort, safety and security, fare, and environment).

\section{Method}

\subsection{Data Collection}

The object of this study is the paratransit service in Bandung, Indonesia. The community knows it very well, as it has been available for a long time. It is called Angkutan kota, which people simplify as Angkot. Data were collected by distributing online questionnaires, 
as face-to-face meeting is restricted in Indonesia due to social distancing resulting from the COVID-19 pandemic. The respondents were approached using social media, as well as a snowballing effect from friend to friend. As this study is mode-specific, it is acceptable to conduct non-probability sampling. Non-probability sampling using an online survey is a potential method of investigating certain characteristics or phenomena [67], as in the case of paratransit users in Bandung.

The respondents were able to complete the questionnaire online in the period from 23 July up to 1 August 2021. The questionnaire was closed when a sample size of 400 respondents was reached, being the minimum sample size, calculated using Yamane's equation [68] with a $5 \%$ level of significance and a population of 2.5 million. Since the questionnaire was distributed online, we included a question to restrict it only to respondents who had experience of using paratransit and who resided in the Bandung Metropolitan Area. This filtering question was provided to eliminate the possibility of survey bias by ensuring only the proper respondents were included. The filtering question was also beneficial in eliminating the possibility of non-response bias. With an average of five minutes to fill the questionnaire using a commercial online survey platform, this study was able to collect a total of 415 responses. After completing the questionnaire, we provided a reward for some randomly selected respondents to reduce the possibility of non-response bias. After evaluating the completeness of the questionnaire, a sample of 400 respondents was kept for further analysis.

In order to eliminate the possibility of survey bias, a pilot survey was conducted. The survey assistant recorded all comments from the respondents and made revisions to ensure the quality of the questionnaire during the pilot survey. The questionnaire was developed by the authors following the previous study by Joewono and Kubota [11] with some modifications, namely adding questions related to ICT, ride sourcing, and future decisions in hypothetical paratransit service scenarios. Thus, there should have very little possibility of bias in this data collection process. Moreover, the quality of this questionnaire was shown by its reliability value, namely a Cronbach's alpha as high as 0.949 , where a value above 0.9 indicates an excellence level of reliability.

This five-page online questionnaire can be divided into four parts, namely general questions, perception of satisfaction, frequency of negative experiences, and user loyalty. The questionnaire's front page was the introduction to the respondent, including related information about the survey and informed consent. The general part with 14 questions covered socio-economic and trip characteristics, as well as overall satisfaction. The second part consisted of questions concerning the quality of service, featuring nine groups of aspects with a total of 54 items, where several items covered each aspect. Responses were provided on a five-point scale from one (very dissatisfied) to five (very satisfied). The third part consisted of seven aspects, each aspect consisting of questions regarding the frequency of negative experiences while using paratransit. Ratings were also provided on a five-point scale, ranging from one (very often) to five (never). The last part consisted of questions regarding the respondents' loyalty. The respondents were asked whether they would use paratransit in the future or change mode to motorcycle-based ride sourcing (MBRS) or car-based ride sourcing (CBRS) for five different scenarios. The respondents were also asked whether they would recommend the use of paratransit, MBRS or CBRS to others in five different scenarios.

\subsection{Proposed Model}

Figure 1 shows the structure of the model. The hierarchical SEM model is estimated as a way to better understand the relationship between satisfaction and loyalty to paratransit. The model also investigates the interactions between factors that influence those variables. The proposed model and hypotheses were developed based on the literature in the previous section. The interaction between satisfaction and loyalty was based on standard satisfaction-loyalty theory [54]. Satisfaction with the mode is explained by nine aspects of paratransit service quality following the study by Joewono and Kubota [11] 
(i.e., availability, accessibility, reliability, information, customer service, comfort, safety and security, fare, and environment), developed based on a rigorous literature review [69,70]. It is reasonable to consider these aspects and attributes as relevant to the current situation of operation of paratransit in Bandung, Indonesia. The literature also shows that the aspects and attributes in Joewono and Kubota [11] have formed the basis study for paratransit studies in the last two decades: for example, they can be found in the studies by Tiglao et al. [42], Sharma et al. [43], or Sharma and Pandit [71], which implies their relevance to the current study about service quality of paratransit and satisfaction. Furthermore, the component of loyalty refers to the operational definition of loyalty [47], while the option of decision is adjusted to paratransit or ride sourcing, whether MBRS or CBRS.

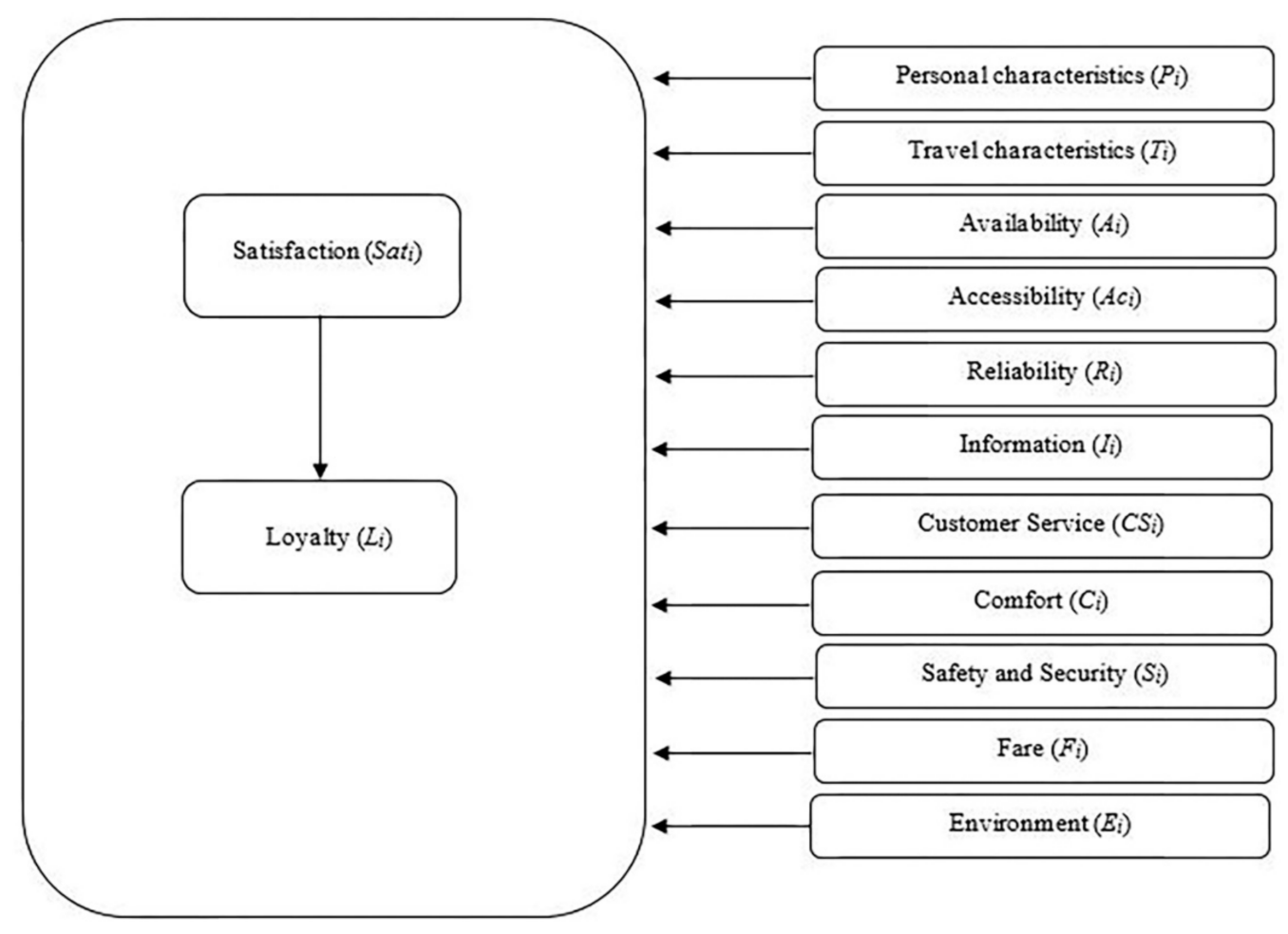

Figure 1. The hypothesized structure of the model.

Hierarchical SEM was used to test the hypotheses. Satisfaction and loyalty were analysed in the model as endogenous variables, while all other variables were treated as exogenous. Hierarchical SEM is a multilevel regression analysis or multilevel SEM [72] that uses an instrumental variable (IV) to tackle the endogeneity issue and can specify the direct and indirect causal effects between clusters [73,74]. With the concept of analysis of hierarchically clustered data, this method is similar to the two- and three-stage least squares methods (2SLS and 3SLS) [72]. Hierarchical SEM has more advantages than traditional SEM [73] since it requires less computational time compared to multilevel path analysis models and is able to include multiple endogenous variables or multiple equations. The application is commonly used as it is able to fix some variables constantly by including multiple groups or nesting datasets [72,74]. Moreover, compared to the similar structural model, the hierarchical SEM can accommodate categorical variables that cannot be analysed by SEM or the partial least squares SEM (PLS-SEM) [75]. The hierarchical SEM also has more flexibility in accommodating various types of independent variables that are generated separately using various exploratory methods, such as explanatory factor analysis (EFA), cluster analysis (CA), or confirmatory composite analysis (CCA). Take the work by Dharmowijoyo et al. [73], for example, who analysed the effects of past behaviour, behaviour desire, behaviour volition and the duration of discretionary activities in four hierarchies. Rather than the simultaneous analyses provided by PLS-SEM or SEM, 
hierarchical SEM requires staged computation that depends on the hierarchical structure and the nesting effect of the model. The complex hierarchical structure requires more steps in parameter estimation, as well as computation of the IV. Detailed discussion of hierarchical SEM can be found elsewhere [72-79].

The estimation of satisfaction $\left(S a t_{i}\right)$ is like the estimation of IV in the first stage of 2SLS, whereas the incorporation of estimated job satisfaction ( $\widehat{\mathrm{Sat}}_{i}$ ) into the loyalty model is like the second stage of 2SLS. As in 2SLS, the inclusion of $\left(\widehat{S a t}_{i}\right)$ or estimated satisfaction tries to tackle endogeneity problems using paratransit $\left(\right.$ Sat $\left._{i}\right)$ and other observed variables (personal characteristics, travel characteristics, availability, accessibility, reliability, information, customer service, comfort, safety and security, fare, and environment). The detailed equations are shown in Equations (1) and (2). The equations for this study were run separately for the first and the second stages; thus, the estimated error terms are assumed not to be correlated.

Ordinary multiple linear regression is used in the model of satisfaction with the use of paratransit. As the first stage, the equation to estimate satisfaction is provided below:

$$
\text { Sat }_{i}=\alpha_{1}+\left(\beta_{1} P_{i}+\beta_{2} T_{1}+\beta_{3} A_{i}+\beta_{4} A c_{i}+\beta_{5} R_{i}+\beta_{6} I_{i}+\beta_{7} C S_{i}+\beta_{8} S_{i}+\beta_{9} F_{i}+\beta_{10} E_{i}\right)
$$

where $S a t_{i}$ is the satisfaction of individual $I, \alpha$ is the estimated constant, $\beta$ is the estimated coefficient of parameters, $P_{i}$ is personal characteristics, $T_{i}$ is travel characteristics, $A_{i}$ is availability, $A c_{i}$ is accessibility, $R_{i}$ is reliability, $I_{i}$ is information, $C S_{i}$ is customer service, $C_{i}$ is comfort, $S_{i}$ is safety and security, $F_{i}$ is fare, and $E_{i}$ is environment.

In the estimation of loyalty in the second-stage model, this study incorporates $\widehat{S a t}_{i}$ (estimated satisfaction for paratransit user $i$ ), estimated from the satisfaction model. Endogeneity problems were expected to be tackled by applying $\widehat{S a t}_{i}$ instead of $S a t_{i}$. The recursive structure between satisfaction and loyalty is represented by applying $\widehat{S a t}_{i}$ in the second stage model. The equation to estimate job satisfaction in the second stage is estimated using binary logistic regression, as provided below:

$$
L_{i}=\frac{\exp \left(\alpha_{2}+\left(\beta_{11} P_{i}+\beta_{12} T_{i}+\beta_{13} A_{i}+\beta_{14} A c_{i}+\beta_{15} R_{i}+\beta_{16} I_{i}+\beta_{17} C S_{i}+\beta_{18} S_{i}+\beta_{19} F_{i}+\beta_{20} E_{i}\right)+\gamma_{1} \widehat{S a t}_{i}\right)}{1+\exp \left(\alpha_{2}+\left(\beta_{11} P_{i}+\beta_{12} T_{i}+\beta_{13} A_{i}+\beta_{14} A c_{i}+\beta_{15} R_{i}+\beta_{16} I_{i}+\beta_{17} C S_{i}+\beta_{18} S_{i}+\beta_{19} F_{i}+\beta_{20} E_{i}\right)+\gamma_{1} \widehat{S a t}_{i}\right)}
$$

where $L_{i}$ is the probability of the paratransit user being loyal, and $\alpha, \gamma$ and $\beta$ are the estimated coefficients of parameters in the hierarchical SEM. The estimation of both models employed the stepwise method. The stepwise method is a step-by-step iterative construction of a regression model that involves the selection of independent variables to be used in a final model [80]. Several insignificant variables are retained in the models due to interactions with the goodness-of-fit of the models after a review during the stepwise process [81].

\subsection{Data Description}

From the collected responses, this study found that paratransit user respondents in Bandung were mainly young and productive, 90 per cent being aged 19 to 50 years. Most respondents were women $(51 \%)$, single $(76 \%)$, and lived in the territory of Bandung City (78\%). Users had a diploma or bachelor's degree as their highest education (54\%). Most users were students (39\%) or entrepreneurs (30\%). Their monthly income was in the range of three million to six million IDR (207-414 USD) (36\%), while the monthly basic salary in the Bandung area is three million IDR. Around 30 per cent of users had a monthly income of less than three million IDR or more than six million IDR. Most respondents did not own any vehicle at home (41\%), while the rest had at least one motorcycle at home. Reasons for using paratransit were their higher preference for Angkot over other modes of PT in Bandung $(40 \%)$, did not have a vehicle $(36 \%)$, and could not drive $(24 \%)$. Their average use per week was one round trip (72\%). Trip destinations were dominated by educational institutions (33\%) and working or shopping (38.5\%). Respondents reported that they spent between 2500 IDR (17.24 US cents) and 5000 IDR (34.48 US cents) to use the service. Almost all respondents (90\%) spent less than 10,000 IDR (69 US cents). Around 51 per cent of respondents reached the Angkot stop by walking and 30 per cent were dropped off by 
family or friends. Table 1 presents the characteristics of the respondents and their travel using paratransit.

Table 1. Characteristics of the respondents.

\begin{tabular}{|c|c|c|c|c|c|}
\hline Category & Description & Percentage & Category & Description & Percentage \\
\hline \multirow{7}{*}{ age (years) } & 15 or younger & 5.75 & \multirow{8}{*}{ vehicle ownership } & do not have a vehicle & 40.75 \\
\hline & $16-18$ & 4.25 & & have only a motorcycle & 14.50 \\
\hline & $19-23$ & 44.00 & & have only a car & 6.50 \\
\hline & $24-30$ & 29.25 & & have only nmt vehicle & 15.25 \\
\hline & $31-40$ & 11.25 & & have car and motorcycle & 5.25 \\
\hline & $41-50$ & 4.75 & & have motorcycle and nmt vehicle & 6.25 \\
\hline & above 50 & 0.75 & & have car and nmt vehicle & 7.50 \\
\hline \multirow[t]{2}{*}{ gender } & male & 48.50 & & $\begin{array}{l}\text { have car, motorcycle and nmt } \\
\text { vehicle }\end{array}$ & 4.00 \\
\hline & female & 51.50 & \multirow{3}{*}{$\begin{array}{l}\text { reasons to use } \\
\text { Angkot }\end{array}$} & cannot drive & 23.75 \\
\hline \multirow{2}{*}{ marital status } & single & 76.00 & & do not have a vehicle & 36.50 \\
\hline & married & 24.00 & & prefer to use Angkot over other pt & 39.75 \\
\hline \multirow{4}{*}{$\begin{array}{c}\text { last } \\
\text { education }\end{array}$} & junior high school & 7.00 & \multirow{3}{*}{$\begin{array}{l}\text { frequency of usage } \\
\text { (trips) }\end{array}$} & once a week & 71.75 \\
\hline & high school & 34.75 & & twice a week & 23.50 \\
\hline & diploma/bachelor's degree & 54.00 & & three times a week or more & 4.75 \\
\hline & master's/doctoral degree & 4.25 & \multirow{5}{*}{ trip destination } & educational institution & 33.00 \\
\hline \multirow{6}{*}{ occupation } & student & 39.25 & & work & 20.75 \\
\hline & civil servant & 12.00 & & shop & 17.75 \\
\hline & labourer & 3.00 & & social activity & 28.00 \\
\hline & entrepreneur & 30.50 & & other & 0.50 \\
\hline & housewife & 8.50 & \multirow{4}{*}{$\begin{array}{l}\text { method to reach } \\
\text { stop }\end{array}$} & walking & 51.00 \\
\hline & other & 6.75 & & drop-off & 30.25 \\
\hline \multirow{11}{*}{$\begin{array}{c}\text { income } \\
\text { (million idr) }\end{array}$} & lower than 0.5 & 3.00 & & using nmt & 16.00 \\
\hline & $0.5-1$ & 1.50 & & using motorized vehicle & 2.75 \\
\hline & $1-3$ & 26.75 & \multirow{4}{*}{ fare (IDR) } & $<2500$ & 18.75 \\
\hline & $3-6$ & 36.25 & & $2500-5000$ & 59.25 \\
\hline & $6-10$ & 22.00 & & $7500-10,000$ & 18.75 \\
\hline & higher than 10 & 10.50 & & $>10,000$ & 3.25 \\
\hline & & & \multirow{5}{*}{ place of living } & Bandung City & 77.75 \\
\hline & & & & West Bandung & 16.00 \\
\hline & & & & Cimahi & 4.50 \\
\hline & & & & Sumedang & 0.75 \\
\hline & & & & other & 1.00 \\
\hline
\end{tabular}

NMT = non-motorized vehicle.

Users' perceptions regarding their satisfaction with the paratransit service are summarized according to the aspects of satisfaction (Table 2). Using a five-point satisfaction scale ranging from one (very dissatisfied) to five (very satisfied), users show that all nine aspects are rated lower than the median of three. The range of the average rating is quite small, from 2.63 for the safety and security aspects, and up to 2.89 for availability aspects. The standard deviation in responses seems to be similar; the value of standard deviation ranged 
from 0.70 to 0.82 . This implies little variation among variables. Table 3 presents details of the satisfaction rating for all 54 items of service quality. Using more detailed variables, it can be seen that users were not satisfied with the service quality, ratings ranging from 2.52 to 3.00 . The variation in perception seems similar among service quality variables, i.e., from 0.68 to 0.85 .

Table 2. Summary of users' satisfaction with the paratransit service.

\begin{tabular}{ccc}
\hline Subcategory & M & S.D. \\
\hline Availability & 2.89 & 0.78 \\
Accessibility & 2.76 & 0.73 \\
Reliability & 2.77 & 0.70 \\
Information & 2.74 & 0.73 \\
Customers & 2.75 & 0.74 \\
Comfort & 2.70 & 0.73 \\
Safety and security & 2.63 & 0.75 \\
Fare & 2.83 & 0.82 \\
Environment & 2.77 & 0.73 \\
\hline
\end{tabular}

$\mathrm{M}=$ mean; $\mathrm{SD}$ = standard deviation.

Respondents were also asked to state their perception of their future choice in terms of whether they are likely to use paratransit, MBRS or CBRS for several scenarios. Figure 2 shows respondents' perception of future preferences in terms of their loyalty. For all scenarios, the proportion of respondents who will use paratransit (Angkot) in the future ranges from 20.58 per cent to 23.48 per cent. The lowest preference for paratransit appears in the business-as-usual scenario. When there is a service improvement, the percentage increases by about 3-5 per cent. These values imply the strong competitiveness of ride sourcing-i.e., more than 75 per cent of respondents prefer to use MBRS and CBRS. It is interesting to note that car-based ride sourcing shows lower preference (12.66-31.3\%) than motorcycle-based ride sourcing $(45.38-66.75 \%)$. This is in line with the current situation in Indonesian cities, where the motorcycle is a preferable mode of transport in urban areas.

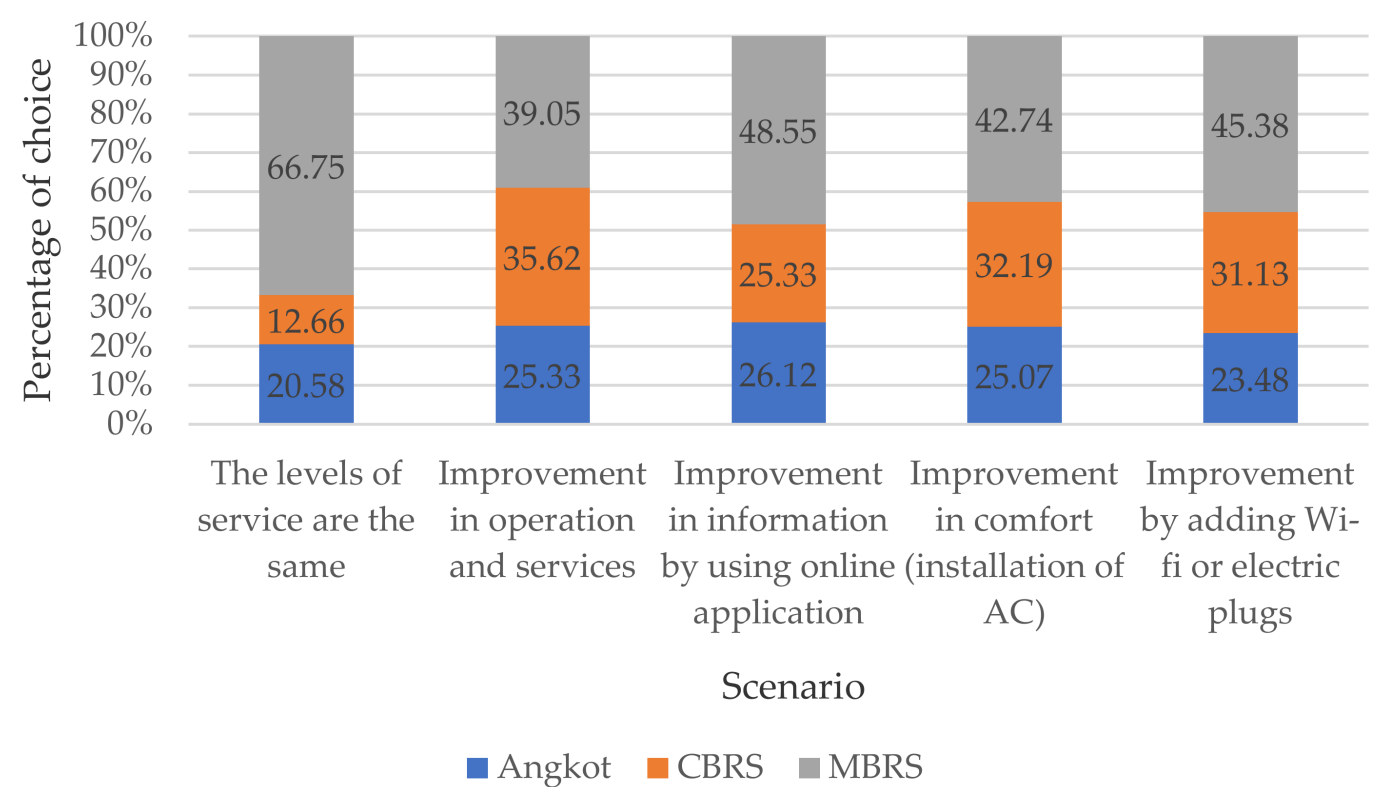

Figure 2. Respondents' loyalty based on scenarios. 
Table 3. Satisfaction rating of the paratransit service.

\begin{tabular}{|c|c|c|c|}
\hline Aspects & Variables & $\mathbf{M}$ & S.D. \\
\hline \multirow{6}{*}{ Availability $(A)$} & area coverage of $A n g k o t$ & 3.00 & 0.82 \\
\hline & distance between Angkot stop and your destination and origin & 2.83 & 0.78 \\
\hline & the suitability of Angkot compared with other PT to help reach the destination & 2.96 & 0.76 \\
\hline & daily operation time of Angkot & 2.84 & 0.80 \\
\hline & frequency of Angkot arrival & 2.88 & 0.74 \\
\hline & other PT alternative, if Angkot cannot be used & 2.83 & 0.78 \\
\hline \multirow{3}{*}{ Accessibility $(A c)$} & obstruction by pedestrian, street vendor or other when using Angkot & 2.84 & 0.74 \\
\hline & quality of Angkot stop facilities & 2.67 & 0.73 \\
\hline & easiness of entering the vehicle & 2.77 & 0.71 \\
\hline \multirow{5}{*}{ Reliability $(R)$} & waiting time at first stop & 2.84 & 0.69 \\
\hline & punctuality of arrival and departure of Angkot from the stop & 2.67 & 0.70 \\
\hline & waiting time in vehicle & 2.77 & 0.68 \\
\hline & waiting time when changing route & 2.76 & 0.70 \\
\hline & number of trip delays due to vehicle damage or something else unexpected & 2.79 & 0.71 \\
\hline \multirow{5}{*}{ Information $(I)$} & easiness of gaining information about Angkot & 2.85 & 0.74 \\
\hline & information quality & 2.63 & 0.71 \\
\hline & information about Angkot route & 2.74 & 0.71 \\
\hline & information about Angkot services & 2.68 & 0.75 \\
\hline & $\begin{array}{l}\text { information in times of emergency about latest conditions and suggestion of } \\
\text { other travel alternatives }\end{array}$ & 2.81 & 0.71 \\
\hline \multirow{7}{*}{ Customer service $(\mathrm{Cs})$} & easiness of making suggestions and complaining to the authority & 2.81 & 0.77 \\
\hline & follow-up about complaint & 2.67 & 0.69 \\
\hline & staff ability to handle passengers' needs & 2.76 & 0.75 \\
\hline & staff attitude towards passengers & 2.79 & 0.76 \\
\hline & assistance to passengers & 2.74 & 0.75 \\
\hline & assistance for passengers with special needs & 2.71 & 0.74 \\
\hline & easiness of payment and receiving change & 2.78 & 0.76 \\
\hline \multirow{8}{*}{ Comfort $(C)$} & air quality and temperature inside vehicle & 2.76 & 0.75 \\
\hline & cleanliness inside vehicle & 2.70 & 0.71 \\
\hline & material quality inside vehicle (seats, lights, furniture) & 2.78 & 0.74 \\
\hline & existence of support tools (AC, communication device, other) & 2.61 & 0.75 \\
\hline & Angkot stop design, including easy movement and queue length & 2.71 & 0.73 \\
\hline & in-vehicle design layout & 2.66 & 0.68 \\
\hline & in-vehicle seating & 2.73 & 0.75 \\
\hline & comfort while riding Angkot from boarding to destination & 2.69 & 0.73 \\
\hline \multirow{6}{*}{ Safety and security $(S)$} & overall safety from crime during day and night & 2.85 & 0.72 \\
\hline & ability and easiness to be observed by officer when in danger & 2.62 & 0.70 \\
\hline & existence of safety tool in case of emergency & 2.54 & 0.80 \\
\hline & effort to prevent harm to users inside the vehicle & 2.52 & 0.78 \\
\hline & overall safety and security while using Angkot & 2.61 & 0.71 \\
\hline & certainty of observing actions that could lead to danger & 2.64 & 0.74 \\
\hline \multirow{5}{*}{ Fare $(F)$} & fare compatibility with utilization for Angkot operation & 2.85 & 0.81 \\
\hline & the amount of money spent when using Angkot & 2.80 & 0.83 \\
\hline & the benefit obtained from using Angkot compared to the cost & 2.83 & 0.76 \\
\hline & the amount of savings when using Angkot rather than other PT & 2.83 & 0.83 \\
\hline & the cost compared to the ability to pay & 2.86 & 0.85 \\
\hline \multirow{9}{*}{ Environment $(E)$} & the level of emissions caused by Angkot & 2.85 & 0.72 \\
\hline & the level of cleanliness of the Angkot stop & 2.62 & 0.70 \\
\hline & resource use by Angkot operation (fuel consumption) & 2.54 & 0.80 \\
\hline & the usage of city space by Angkot operation & 2.52 & 0.78 \\
\hline & Angkot impact on traffic and congestion & 2.61 & 0.71 \\
\hline & the level of road accidents caused by Angkot & 2.64 & 0.74 \\
\hline & the level of road damage due to operation of Angkot & 2.85 & 0.72 \\
\hline & Angkot operation impact on the economic life of the city & 2.62 & 0.70 \\
\hline & Angkot operation impact on social life, culture, and politics & 2.54 & 0.80 \\
\hline
\end{tabular}


Based on these preference data, respondents were clustered into loyal and non-loyal users. Using two-step cluster analysis, respondents can be classified as loyal when they choose Angkot in the five scenarios. Otherwise, they are classified as non-loyal. Analysis shows that using two clusters, 53.8 per cent of respondents are classified as non-loyal and 46.2 per cent as loyal. The two clusters are used as dependent variables in the loyalty model in the second stage modelling using binary logistic regression.

\section{Model Estimation}

The model estimation result for satisfaction as a dependent variable is shown in Table 4. The model has a coefficient of determination $\left(R^{2}\right)$ as high as 0.424 , while the F-test value is 6.258 , with a $p$-value far below 0.05 . This implies that the estimated model is a good model for further interpretation.

The model shows that passengers younger than 30 years and students rated paratransit positively, which influences their satisfaction. This finding is in line with the result that all kinds of occupation other than studying had a negative effect on satisfaction, which implies students' positive image of paratransit. As expected, people with low income had a positive perception of the service, positively influencing satisfaction. People who reached the stop by drop-off and using NMT perceived the service negatively. In terms of fare, people perceived the current fare as negatively influencing their satisfaction with the service. The model shows that people who were not residents of Bandung City gave a negative rating to this service. Surprisingly, people who did not have any vehicle at home gave a negative rating for satisfaction with this service.

The results from the model estimation show that the existing paratransit route has good coverage that satisfies users, which implies an advantage for Angkot in Bandung compared to other PT. Ease of entering the vehicle also positively influenced users' satisfaction. It is interesting to note the positive influence of reliability on users' satisfaction. Two variables were found to be positive and significant in influencing satisfaction, namely punctuality of arrival and departure, and waiting time during transfer, while the number of trip delays due to vehicle problems influenced satisfaction negatively and significantly. With the existing number of Angkot in Bandung-around 5000 registered vehicles but only around 3000 vehicles operating - this mode seems to passengers to be getting easier. As the number of passengers is reducing, the Angkot drivers do not wait for passengers as long as before. They drive the car with the existing passengers, which reduces the travel time and waiting time. This situation, in fact, gradually reduces the income level of the driver or operator, which affects their ability to maintain the car and increases the probability of car damage.

Two information variables are found to be significant in influencing satisfaction. Information about the paratransit's route negatively influences satisfaction. While there are some applications that users can use to find the Angkot's route-for example, Semut [82] or KIRI [83] - users still found it difficult to know the route and this reduced their satisfaction with the mode. Unexpectedly, information in times of emergency, latest conditions and easiness of finding an alternative positively influenced satisfaction. A possible explanation for this finding is the wide and long history of Angkot in Bandung, which makes it easy to find an alternative when passengers experience trouble using the mode. The model also shows that assistance for passengers with special needs positively influences satisfaction. This is understandable, as there are other passengers in the car, and so passengers will easily find help from other passengers when entering or leaving the car. In contrast, assistance of passengers in general has a negative influence on satisfaction. This is because there is limited help from drivers and there is no driver assistant at present, where previously this was common practice. Moreover, for general users, people usually do not take much care of other passengers. Easiness of payment negatively influences satisfaction. As the Angkot fare is small, people will experience a lengthy waiting time to receive change from the driver, as the driver needs to count the change and hand it over. This situation reduces easiness of payment. 
Table 4. Model estimation of satisfaction.

\begin{tabular}{|c|c|c|c|c|c|}
\hline & \multirow{2}{*}{\multicolumn{2}{|c|}{ Variables }} & \multicolumn{2}{|c|}{ Unstd. Coeff. } & \multirow[b]{2}{*}{$t$} \\
\hline & & & B & S.E. & \\
\hline \multirow{2}{*}{ Availability } & \multicolumn{2}{|c|}{ area coverage of $A n g k o t$} & 0.101 & 0.043 & $2.312 * *$ \\
\hline & \multicolumn{2}{|c|}{ the suitability of Angkot route compared with other PT routes to help reach the destination } & 0.057 & 0.045 & 1.245 \\
\hline Accessibility & \multicolumn{2}{|c|}{ easiness of entering the vehicle } & 0.118 & 0.049 & $2.419 * *$ \\
\hline \multirow{3}{*}{ Reliability } & \multicolumn{2}{|c|}{ punctuality of arrival and departure of Angkot from the stop } & 0.097 & 0.048 & $2.039 * *$ \\
\hline & \multicolumn{2}{|c|}{ waiting time when changing route } & 0.119 & 0.049 & $2.445^{* *}$ \\
\hline & \multicolumn{2}{|c|}{ number of trip delays due to vehicle damage or something else unexpected } & -0.086 & 0.047 & $-1.821 *$ \\
\hline \multirow{3}{*}{ Information } & \multicolumn{2}{|c|}{ information about Angkot travel route } & -0.134 & 0.047 & $-2.842 * * *$ \\
\hline & \multicolumn{2}{|c|}{ information about Angkot service for user } & 0.066 & 0.046 & 1.441 \\
\hline & \multicolumn{2}{|c|}{ information in times of emergency, about latest conditions and suggestions of travel alternatives } & 0.144 & 0.051 & $2.804 * * *$ \\
\hline \multirow{3}{*}{$\begin{array}{l}\text { Customer } \\
\text { service }\end{array}$} & \multicolumn{2}{|c|}{ assistance to passengers } & -0.076 & 0.046 & $-1.66^{*}$ \\
\hline & \multicolumn{2}{|c|}{ assistance for passengers with special needs } & 0.101 & 0.045 & $2.248^{* *}$ \\
\hline & \multicolumn{2}{|c|}{ easiness of payment and receiving change } & -0.131 & 0.046 & $-2.832^{* * *}$ \\
\hline Comfort & \multicolumn{2}{|c|}{ in-vehicle design and layout } & -0.091 & 0.049 & $-1.873^{*}$ \\
\hline \multirow{3}{*}{$\begin{array}{l}\text { Safety and } \\
\text { security }\end{array}$} & \multicolumn{2}{|c|}{ overall safety from crime during day and night } & 0.062 & 0.045 & 1.367 \\
\hline & \multicolumn{2}{|c|}{ effort to prevent harm to users inside the vehicle } & 0.055 & 0.045 & 1.219 \\
\hline & overall safety and sec & ity when using Angkot & 0.085 & 0.049 & $1.725 *$ \\
\hline & fare compatibility wit & atilization for Angkot operation & -0.059 & 0.045 & -1.308 \\
\hline Fare & the amount of money & ent when using Angkot & 0.077 & 0.041 & $1.998^{*}$ \\
\hline & the benefit obtained $\mathrm{f}$ & $\mathrm{n}$ using Angkot compared to the cost & 0.071 & 0.048 & 1.477 \\
\hline & the level of cleanlines & f the Angkot stop & 0.13 & 0.046 & $2.845^{* * *}$ \\
\hline & Angkot impact on traf & and congestion & -0.102 & 0.047 & $-2.181^{* *}$ \\
\hline Environment & the level of road dam & due to operation of Angkot & 0.109 & 0.05 & $2.167 * *$ \\
\hline & Angkot operation imp & ton the economic life in this city & -0.098 & 0.047 & $-2.073 * *$ \\
\hline & Angkot operation imp & t on social life, culture and politics & 0.067 & 0.053 & 1.263 \\
\hline & & 16-18 years old (D) & 0.338 & 0.15 & $2.248^{* *}$ \\
\hline & Age & $24-30$ years old $(\mathrm{D})$ & 0.288 & 0.074 & $3.873^{* * *}$ \\
\hline & & $31-40$ years old $(\mathrm{D})$ & 0.156 & 0.106 & 1.477 \\
\hline & & above 50 years old $(\mathrm{D})$ & 0.479 & 0.364 & 1.317 \\
\hline $\begin{array}{l}\text { Personal } \\
\text { characteris- }\end{array}$ & Last Education & junior high school (D) & 0.156 & 0.134 & 1.162 \\
\hline & & high school (D) & 0.136 & 0.069 & $1.982 * *$ \\
\hline & & civil servant (D) & -0.273 & 0.101 & $-2.691 * * *$ \\
\hline & Occupation & entrepreneur (D) & -0.184 & 0.080 & $-2.304 * *$ \\
\hline & & housewife (D) & -0.356 & 0.121 & $-2.936^{* * *}$ \\
\hline & Income & Rp.1,000,000-Rp.3,000,000 (D) & 0.157 & 0.069 & $2.26^{* *}$ \\
\hline & To reach stop & drop off (D) & -0.157 & 0.066 & $-2.384^{* *}$ \\
\hline & & using non-motorized vehicle (D) & -0.17 & 0.084 & $-2.021 * *$ \\
\hline & & under Rp.2500 (D) & -0.346 & 0.078 & $-4.444^{* * *}$ \\
\hline Travel char- & Angkot rate & Rp.7500-Rp.10,000 (D) & -0.177 & 0.076 & -1.527 \\
\hline acteristics & & above Rp.10,000 (D) & -0.252 & 0.167 & -1.505 \\
\hline & Location & Sumedang (D) & -0.579 & 0.359 & -1.611 \\
\hline & Vehicle ownership & do not have any (D) & -0.214 & 0.066 & $-3.244^{* * *}$ \\
\hline & & only have non-motorized vehicle (D) & -0.145 & 0.088 & -1.638 \\
\hline Constant & & & 1.212 & 0.225 & $5.376^{* * *}$ \\
\hline $\mathrm{R}^{2} ; \mathrm{F} ; p$-value & & & & $24 ; 6.25$ & 0.000 \\
\hline
\end{tabular}

${ }^{*}$ Significant at $10 \%$; ${ }^{* *}$ significant at $5 \%$; ${ }^{* * *}$ significant at $1 \%$; SE = standard error; D = dummy $(1=$ yes, $0=$ otherwise). 
The model also found that current layout and design of the vehicle significantly reduces users' satisfaction. The most probable reason is the quality of seats and layout that constrain passengers' free movement inside the car. It is also a fact that the current cars are quite old. For general safety and security, users tend to give a positive rating that increases their satisfaction. Users found the fare acceptable and gave a positive rating that influenced their satisfaction. People rated the paratransit stop (shelter) positively and were satisfied with it. This is mainly because paratransit can stop almost anywhere, and users will select the most favourable place for them: thus, the passenger decides the location of the stop. People also rate paratransit as having a minimal impact on road quality, and they are satisfied with it. Interestingly, people rate paratransit as having a negative impact on traffic congestion and on economic life in the city. This implies a long and widely negative image of paratransit in the community.

Table 5 presents the estimated model of binary logistic regression as the second stage of the hierarchical SEM for investigating loyalty. The dependent variables are "loyal" and "non-loyal". The predictors are personal and travel characteristics, service quality attributes, and estimated satisfaction. The estimated model has a $p$-value for omnibus goodness-of-fit test far below 0.05 , which indicates a well-performing model. It implies that the model with predictors is significantly different from the model without predictors. Our binary logistic model has a Hosmer and Lemeshow $(\mathrm{H}-\mathrm{L})$ goodness-of-fit test statistic greater than 0.05 , as is required for well-fitting models. In this case, we fail to reject the null hypothesis that there is no difference between the observed and model-predicted values, implying that the model's estimates fit the data at an acceptable level. This desirable outcome of a non-significant $\mathrm{H}$ - $\mathrm{L}$ test indicates that the model prediction does not significantly differ from that observed. This model has a Cox and Snell $R^{2}$ value of 0.304 and a Nagelkerke $\mathrm{R}^{2}$ of 0.407. The estimated model also has an overall percentage correct as high as 75.5. From those statistics, it can be concluded that the model is a good model for further interpretation.

The results of the model estimation show that young and productive users (24-30 years old) tend to be more loyal, while younger people with a highest education of high school are more likely to change from paratransit to other modes. From the occupation background, only students intend to be loyal in the future. People with income of 1-3 million IDR tend to be more loyal, having a monthly income lower than the average monthly wage for the Bandung area. Surprisingly, people without a vehicle at home intend to be less loyal in the future. The model shows that people who tend to be loyal are people with low economic capacity. This is in line with the model, wherein total satisfaction with the service does not significantly influence loyalty.

Based on the service quality variable, the model shows that people's experience of information about emergency situations in the operation of paratransit tends to influence passenger loyalty negatively. There is a similar finding for the assistance of passengers with special needs. People tend to be loyal when they experience a positive advantage with the current payment method. This is similar to the variable of prevention of harmful incidents inside the car when using the mode. People who perceive the service positively in terms of the impact on traffic and on culture, economic and social life tend to be more loyal to paratransit. On the other hand, people who are aware of the impact of paratransit on road conditions are likely to be less loyal in the future.

Table 5. Model estimation of loyalty.

\begin{tabular}{|c|c|c|c|c|}
\hline & Variables & B & S.E. & Wald \\
\hline Availability & area coverage of $A n g k o t$ & 0.208 & 0.207 & 1.008 \\
\hline Accessibility & easiness of entering the vehicle & -0.337 & 0.261 & 1.662 \\
\hline \multirow{2}{*}{ Reliability } & punctuality of arrival and departure of Angkot from the stop & -0.295 & 0.24 & 1.509 \\
\hline & waiting time when changing route & -0.283 & 0.25 & 1.281 \\
\hline
\end{tabular}


Table 5. Cont.

\begin{tabular}{|c|c|c|c|c|c|}
\hline \multicolumn{3}{|r|}{ Variables } & B & S.E. & Wald \\
\hline Information & \multicolumn{2}{|c|}{$\begin{array}{l}\text { information in times of emergency, about latest conditions and suggestion } \\
\text { of alternative travel }\end{array}$} & -0.511 & 0.248 & $4.264 *$ \\
\hline \multirow{3}{*}{ Customer service } & \multicolumn{2}{|c|}{ assistance of passengers } & 0.193 & 0.2 & 0.929 \\
\hline & \multicolumn{2}{|c|}{ assistance for passengers with special needs } & -0.719 & 0.231 & $9.702 * *$ \\
\hline & \multicolumn{2}{|c|}{ easiness of payment and receiving change } & 0.648 & 0.27 & $5.779 *$ \\
\hline Comfort & \multicolumn{2}{|c|}{ in-vehicle design and layout } & -0.307 & 0.212 & 2.098 \\
\hline \multirow{2}{*}{ Safety and security } & \multicolumn{2}{|c|}{ overall safety from crime during day and night } & -0.221 & 0.2 & 1.217 \\
\hline & \multicolumn{2}{|c|}{ effort to prevent harm to users inside the vehicle } & 0.414 & 0.195 & $4.523 *$ \\
\hline \multirow{5}{*}{ Environment } & \multicolumn{2}{|c|}{ level of cleanliness of the Angkot stop } & -0.42 & 0.242 & 3.007 \\
\hline & \multicolumn{2}{|c|}{ Angkot impact on traffic and congestion } & 0.764 & 0.242 & $9.978 * *$ \\
\hline & \multicolumn{2}{|c|}{ level of road damage due to operation of $A n g k o t$} & -0.931 & 0.279 & $11.097^{* *}$ \\
\hline & \multicolumn{2}{|c|}{ Angkot operation impact on the economic life in this city } & 0.539 & 0.237 & $5.198 *$ \\
\hline & \multicolumn{2}{|c|}{ Angkot operation impact on social life, culture and politics } & 0.536 & 0.245 & $4.782 *$ \\
\hline \multirow{8}{*}{$\begin{array}{c}\text { Personal } \\
\text { characteristics }\end{array}$} & \multirow{2}{*}{ Age } & 16-18 years $(\mathrm{D})$ & 1.215 & 0.783 & 2.407 \\
\hline & & $24-30$ years $(\mathrm{D})$ & 1.984 & 0.499 & $15.839^{* *}$ \\
\hline & \multirow{2}{*}{ Highest education } & junior high School (D) & -1.45 & 0.601 & $5.828^{*}$ \\
\hline & & high School (D) & 0.359 & 0.331 & 1.177 \\
\hline & \multirow{3}{*}{ Occupation } & civil servant (D) & -1.031 & 0.57 & 3.266 \\
\hline & & entrepreneur (D) & -0.558 & 0.406 & $1.887 *$ \\
\hline & & housewife (D) & -1.592 & 0.72 & $4.889 *$ \\
\hline & Income & Rp.1,000,000-Rp.3,000,000 (D) & 1.648 & 0.39 & $17.840^{* *}$ \\
\hline \multirow{4}{*}{$\begin{array}{c}\text { Travel } \\
\text { characteristics }\end{array}$} & $\begin{array}{l}\text { Method to reach } \\
\text { stop }\end{array}$ & using non-motorized vehicle (D) & -0.467 & 0.372 & 1.582 \\
\hline & \multirow{2}{*}{ Angkot rate } & under Rp.2500 (D) & -0.541 & 0.551 & 0.963 \\
\hline & & Rp.7500-Rp.10,000 (D) & -0.777 & 0.33 & $5.559 *$ \\
\hline & \multicolumn{2}{|r|}{ do not have any (D) } & -1.362 & 0.375 & $13.216^{* *}$ \\
\hline \multicolumn{3}{|c|}{ Estimated satisfaction } & 5.002 & 1.274 & 15.408 \\
\hline \multicolumn{3}{|l|}{ Constant } & -7.525 & 1.827 & 16.956 \\
\hline \multicolumn{3}{|c|}{ Omnibus test ( $\chi^{2} ;$ df.; $p$-value $)$} & \multicolumn{3}{|c|}{$145.205 ; 29 ; 0.000$} \\
\hline \multicolumn{3}{|c|}{ Hosmer and Lemeshow test ( $\chi^{2} ; \mathrm{df} . ; p$-value) } & \multicolumn{3}{|c|}{$3.277 ; 8 ; 0.916$} \\
\hline \multicolumn{3}{|c|}{$\mathrm{R}^{2}$ Cox and Snell, Nagelkerke } & \multicolumn{3}{|c|}{$0.304 ; 0.407$} \\
\hline Overall percentage & orrect & & & 75 & \\
\hline
\end{tabular}

* Significant at $5 \% ;{ }^{* *}$ significant at $1 \% ; \mathrm{D}=$ dummy $(1=$ yes; $0=$ otherwise $)$.

\section{Discussion and Conclusions}

This study investigates the loyalty of paratransit users in the era of competition from urban transport modes. Urban transport, whether it is mass transit or paratransit, is being greatly impacted by the massive growth of online transportation services-i.e., ride sourcing. Even though the impact is not conclusive in the literature [17-27], the crucial impact is on the substitution effect, where the existence of paratransit is threatened. One crucial effect is on the existence of paratransit in developing countries. Compared to recent studies about paratransit $[43,52,71,84,85]$, this study fills the knowledge gap regarding the future of paratransit in a developing country in terms of loyalty in competition with motorcycle-based or car-based ride sourcing. Using a hierarchical SEM model, this study 
analysed data from users of a paratransit service, Angkot, to investigate the effect of satisfaction on loyalty. The investigation employed nine aspects with 54 service quality attributes, based on the study by Joewono and Kubota [11]. The base hypothesis refers to satisfaction-loyalty theory, based on the study by Jen et al. [54].

This study found that several items of service quality positively influence satisfaction. In general, the existing paratransit service in Bandung is perceived as low quality, which relates to the level of satisfaction. Some unique characteristics seem to be appreciated, such as the easiness of finding a car, as more than 3000 cars out of the 5000 registered cars are available throughout the city. To some extent this provides flexibility for users, but at the same time it creates an impact on traffic congestion. The flexibility of users in paying the fare, where it is sometimes possible for users to pay less than the standard fare, seems to be perceived as unreliable. The size of the car, with 12-14 seats, and the seat arrangement offer the advantage of transporting many people in one trip, while at the same time it is perceived as uncomfortable. While this finding implies users' appreciation of the unique characteristics of paratransit-i.e., Angkot-in Bandung, users' appreciation is changing as their expectations change. The appearance of ride sourcing has had a real impact, as communities can easily compare the paratransit and ride-sourcing services. This model found that people who are satisfied with paratransit are people with limited capability or limited choices. The limitation appears in young people and those with low income. It implies the existence of captive users and the importance of paratransit services to the group of society with more constraints and greater vulnerability. This finding shows the differences between the attitudinal and behavioural levels of loyalty $[30,31,52,53]$ to paratransit. On the other hand, this finding warns of the high probability of mode-changing behaviour from paratransit to another mode. This study supports the findings which conclude that this is a difficult time for paratransit [27-29] or other traditional modes in this competitive era [86]. Moreover, this study showed conditional loyalty, which differentiates the study from common studies regarding loyalty. It is generally accepted that loyalty will retain current passengers [34-37].

The findings from the first stage of the model support the findings of the second stagei.e., the effect of satisfaction on loyalty. The second stage shows the characteristics of people who have a tendency to be loyal. Again, several unique characteristics of paratransit seems to be appreciated and positively influence the tendency towards loyalty. It is interesting to note that people who perceive the service positively in terms of its impact on traffic and on culture and economic and social life tend to be more loyal to paratransit. The model found that many service-quality variables have a negative sign, which implies a negative loyalty tendency. The model also shows that current conditions constrain them to use the service, but when the constraints are relieved, then they intend to change to the use of another mode. On the one hand, the findings of this study are in line with standard satisfactionloyalty theory [54] as well as the generally accepted phenomenon of the influence of service quality on loyalty $[33,35,37]$. On the other hand, this study is able to reveal the positive and unique characteristics of the mode, and the negative characteristics of the mode in terms of its points of weakness. The finding of the strengths and weaknesses of the paratransit service differentiate this study from previous studies, especially about paratransit.

Based on this study, it can be concluded that satisfaction is positively influenced by the variables of service quality. Although there is reduced satisfaction compared to the previous decade, satisfaction with the service still has a positive influence on total satisfaction with the mode. It can also be concluded that satisfaction positively influences loyalty. Satisfaction with the image and unique characteristics of paratransit retains passengers to be loyal in the future. It is interesting to note that current personal and travel characteristics of passengers constrain them to be loyal. It warns of the probability of mode changing in the future. 


\section{Recommendations and Future Work}

Based on the findings from this study, some recommendations can be proposed to retain passengers-i.e., to increase users' loyalty. On the one hand, this study confirms the recommendations from previous studies [40,87]-i.e., the need for greater commitment from the government to public transport development, improvement of existing public transport conditions, development of a unique approach for each developing country, and knowing the users better. On the other hand, this study sheds light on the effects of ICT on paratransit, which is still rare in the literature. Thus, our recommendations can be described in three areas.

The first area is improvement of the current operation of paratransit. This improvement should be interpreted as reformulating the business model of paratransit. The government should pay more attention to and help reform the service. If business-as-usual is applied, then sooner or later paratransit will end. Reform is an urgent step to establish a healthier business model that will enable the quality of service to be improved. It includes a need to re-route the service and establish the service in a more suitable hierarchy of urban public transport.

The second area for improvement is the quality of the service by adopting current trends and technologies. As communities and technologies are changing at a great pace, the current paratransit service cannot be maintained. Change of service by adopting available advancement of ICT is a must. Several studies have indicated that an application designed for public transport can be effective. Real-time information offered by public transport mobile applications enhances the usability of public transport [88]. An initiative to adopt information technology should be supported-for example, information to find paratransit routes, such as KIRI [83] or Semut [82], should be made available. Other facilities and the adoption of best practice in providing a service are promising. Mallat [89] shows that mobile payment or e-payment offers passengers remote and ubiquitous access to payment services, queue avoidance, simplicity, and availability. Introducing an integrated ticketing system can directly lead to increased PT patronage [90-93], including e-payment methods-for example, QR codes and radio-frequency identification (RFID) tags [94,95]. Informative signs for paratransit services at stops or even in the vehicle also promise to improve marketing and communication of the service [96]. Furthermore, it should be noted that service improvement should consider the negative experiences of users, as suggested by Joewono and Kubota [12].

The third area for improvement is knowing the users better. This, as stated by Tarigan et al. [40], is key to the case of paratransit, where the users can be classified as the captive or adapter. Specifically, this study shows that specific groups of respondents tend to be more loyal. This implies the need to focus on some communities or groups as the target market. In general, understanding the target market will be beneficial in designing a suitable service that matches users' expectations. It becomes more crucial in the era of competition with ride sourcing, while paratransit is still the choice for younger and low-income groups who have various constraints in choosing modes (i.e., licence limitation and financial capacity). Maintaining sustainability, affordability and a quality service will provide inclusive accessibility for people's mobility.

While this study contributes to knowledge about the loyalty of paratransit users, it has its limitations. The sample was obtained from only one city, and a wider sample from different cities would provide a broader picture of paratransit users' loyalty. The other limitation lies in the scenarios provided to respondents. More comprehensively stated preference scenarios would be beneficial to gain a deeper understanding of respondents ${ }^{\prime}$ needs and future decisions. Thus, further work involves investigating paratransit users from a wider range of backgrounds to develop a big picture of paratransit users as a way to know them better. Further work should also include a study investigating the preferences and sensitivities of respondents to variables related to urban transport policiesfor example, price, service quality, or routing. 
Author Contributions: Conceptualization, T.B.J.; methodology, T.B.J., A.M. and M.R.; software, A.M. and M.R.; validation, T.B.J., A.M. and M.R.; formal analysis, A.M.; data curation, A.M.; original draft preparation, T.B.J., A.M. and M.R.; review and editing, T.B.J. and A.M.; supervision, T.B.J.; funding acquisition, T.B.J. All authors have read and agreed to the published version of the manuscript.

Funding: The authors would like to thank the Directorate of Research and Community Services, the Directorate General of Research and Development Strengthening, and the Ministry of Research, Technology and Higher Education of the Republic of Indonesia, who provided the research grant (013/SP2H/RDPKR-JAMAK/LL4/2021 \& III/LPPM/2021-07/127-PE).

Institutional Review Board Statement: The study was conducted according to the guidelines of the Declaration of Helsinki, and approved by the Institutional Review Board (or Ethics Committee) of UNIVERSITAS KATOLIK PARAHYANGAN (Number III/LPPM/2021-10/304-I and date of approval 26 October 2021).

Informed Consent Statement: Informed consent was obtained from all subjects involved in the study.

Data Availability Statement: Data sharing not applicable.

Acknowledgments: The authors thank the editor and reviewers. The authors also thank Iwan Suwandana for managing the project, including all parties who participated in this study.

Conflicts of Interest: The authors declare no conflict of interest.

\section{References}

1. Anderson, D.N. Not just a taxi? For-profit ridesharing, driver strategies, and VMT. Transportation 2014, 41, 1099-1117. [CrossRef]

2. Lavieri, S.P.; Dias, F.F.; Juri, N.R.; Kuhr, J.; Bhat, C.R. A model of ride sourcing demand generation and distribution. Transp. Res. Rec. J. Transp. Res. Board 2018, 2672, 31-40. [CrossRef]

3. Uber Blog. Uber Hits 5 Billion Rides Milestone. Available online: https://www.uber.com/en-SG/blog/uber-hits-5-billion-ridesmilestone/ (accessed on 1 August 2021).

4. Metcalfe, G.; Warburg, J. A policy agenda for the sharing economy. The Urbanist 2012, 517. Available online: https: / /www.spur. org/publications/urbanist-article/2012-10-09/policy-agenda-sharing-economy (accessed on 1 August 2021).

5. Silver, N.; Fischer-Baum, R. Public Transit Should Be Uber's New Best Friend. FiveThirtyEight 2015. Available online: https: / / fivethirtyeight.com/features/public-transit-should-be-ubers-new-best-friend/ (accessed on 1 September 2021).

6. Icasiano, C.D.A.; Taeihagh, A. Governance of the risks of ridesharing in Southeast Asia: An in-depth analysis. Sustainability 2021, 13, 1-32. [CrossRef]

7. Rizki, M.; Joewono, T.B.; Dharmowijoyo, D.B.; Prasetyanto, D. The effects of on-and before-journey advantages using ridesourcing in Indonesia. Sustainability 2021, 13, 11117. [CrossRef]

8. Gojek. Sebuah Perjalanan. Available online: https://www.gojek.com/id-id/about/ (accessed on 1 August 2021).

9. Gojek. One App for All Your Needs. 2018. Available online: https:/ /www.go-jek.com/about (accessed on 30 October 2019).

10. Shimazaki, T.; Rahman, M. Physical characteristics of paratransit in developing countries of Asia. J. Adv. Transp. 1996, 30, 5-24. [CrossRef]

11. Joewono, T.B.; Kubota, H. User satisfaction with paratransit in competition with motorization in Indonesia: Anticipation of future implications. Transportation 2007, 34, 337-354. [CrossRef]

12. Joewono, T.B.; Kubota, H. Exploring negative experiences and user loyalty in paratransit. Transp. Res. Rec. 2007, 2034, 134-142. [CrossRef]

13. Mateo-Babiano, I.B.; Guillen, M.D.V.; Susilo, Y.O.; Joewono, T.B. Indigenous transport futures: A strategy for Asian cities toward climate change adaptation. Proc. East. Asia Soc. Transp. Stud. 2011, 16, 1-16.

14. Ross, D.; Alschuler, D. Paratransit-existing issues ad future direction. Transportation 1975, 4, 335-350.

15. Fujiwara, A.; Zhang, J. Sustainable Transport Studies in Asia; Springer: Tokyo, Japan, 2013.

16. Phun, V.K.; Yai, T. State of the art of paratransit literatures in Asian developing countries. Asian Transp. Stud. 2016, 4, 57-77.

17. Rayle, L.; Dai, D.; Chan, N.; Cervero, R.; Shaheen, S. Just a better taxi? A survey-based comparison of taxis, transit, and ride-sourcing services in San Francisco. Transp. Policy 2016, 45, 168-178. [CrossRef]

18. Irawan, M.Z.; Belgiawan, P.F.; Tarigan, A.; Wijanarko, F. To compete or not compete: Exploring the relationships between motorcycle-based ride-sourcing, motorcycle taxis, and public transport in the Jakarta metropolitan area. Transportation 2020, 47, 2367-2389. [CrossRef]

19. Medeiros, R.M.; Duarte, F.; Achmad, F.; Jalali, A. Merging ICT and informal transport in Jakarta's Ojek system. Transp. Plan. Technol. 2018, 41, 336-352. [CrossRef]

20. Feigon, S.; Murphy, C. Shared Mobility and the Transformation of Public Transit. TCRP Research Report, No. 188, Art. No. Project J-11, Task 21. Available online: https:/ / trid.trb.org/view/1416012 (accessed on 16 September 2020).

21. Hall, J.D.; Palsson, C.; Price, J. Is Uber a substitute or complement for public transit? J. Urban Econ. 2018, 108, 36-50. [CrossRef] 
22. Rizki, M.; Joewono, T.B.; Belgiawan, P.F.; Irawan, M.Z. The travel behaviour of ride-sourcing users, and their perception of the usefulness of ride-sourcing based on the users' previous modes of transport: A case study in Bandung City, Indonesia. IATSS Res. 2020, 45, 267-276. [CrossRef]

23. Irawan, M.Z.; Belgiawan, P.F.; Joewono, T.B.; Simanjuntak, N.I.M. Do motorcycle-based ride-hailing apps threaten bus ridership? A hybrid choice modeling approach with latent variables. Public Transp. 2019, 12, 207-231. [CrossRef]

24. Liao, Y. Ride-sourcing compared to its public-transit alternative using big trip data. J. Transp. Geogr. 2021, 95, 103135. [CrossRef]

25. Mostofi, H.; Masoumi, H.; Dienel, H.L. The relationship between regular use of ridesourcing and frequency of public transport use in the MENA region (Tehran and Cairo). Sustainability 2020, 12, 8134. [CrossRef]

26. Clewlow, R.R.; Mishra, G.S. Disruptive Transportation: The Adoption, Utilization, and Impacts of Ride-Hailing in the United States. 2017. UC Davis: Institute of Transportation Studies. Available online: https://escholarship.org/uc/item/82w2z91j (accessed on 1 September 2021).

27. Al Mukaromah, M.; Yuliari, K.; Arifin, M. Dampak Keberadaan transportasi on line terhadap kondisi sosial ekonomi transportasi konvesional di kota kediri. J. Ilm. Mhs. Ekon. 2019, 2, 168-181.

28. Rusyadi, M.K.; Fajarwati, A. Dampak Transportasi Online terhadap keberlanjutan Angkutan kota (Angkot) sebagai transportasi umum perkotaan di kota Bandung. J. Bumi Indones. 2020, 9, 1-16.

29. Robby, M. Pengaruh Keberadaan Ojek Online Terhadap Keberlangsungan Angkot di Kota Pangkalpinang. Ph.D. Thesis, Universitas Bangka Belitung, Merawang Bangka, Indonesia, 2020.

30. Sun, S.; Duan, Z. Modeling passengers' loyalty to public transit in a two-dimensional framework: A case study in Xiamen, China. Transp. Res. Part A Policy Pract. 2019, 124, 295-309. [CrossRef]

31. Webb, V. Customer Loyalty in the Public Transportation Context. Master's Thesis, Massachusetts Institute of Technology, Cambridge, MA, USA, 2010.

32. Li, L.; Bai, Y.; Song, Z.; Chen, A.; Wu, B. Public transportation competitiveness analysis based on current passenger loyalty. Transp. Res. Part A Policy Pract. 2018, 113, 213-226. [CrossRef]

33. $\mathrm{Fu}, \mathrm{X}$. What should we do to enhance your loyalty if you are (dis)satisfied with public transit service? Travel Behav. Soc. 2022, 26, 28-40. [CrossRef]

34. Van Lierop, D.; Badami, M.G.; El-Geneidy, A.M. What influences satisfaction and loyalty in public transport? A review of the literature. Transp. Rev. 2018, 38, 52-72. [CrossRef]

35. Shiftan, Y.; Barlach, Y.; Shefer, D. Measuring passenger loyalty to public transport modes. J. Public Transp. 2015, 18, 1-16. [CrossRef]

36. Vicente, P.; Sampaio, A.; Reis, E. Factors influencing passenger loyalty towards public transport services: Does public transport providers' commitment to environmental sustainability matter? Case Stud. Transp. Policy 2020, 8, 627-638. [CrossRef]

37. Fu, X.-M.; Zhang, J.-H.; Chan, F.T. Determinants of loyalty to public transit: A model integrating Satisfaction-Loyalty Theory and Expectation-Confirmation Theory. Transp. Res. Part A Policy Pract. 2018, 113, 476-490. [CrossRef]

38. Joewono, T.B.; Kubota, H. User perceptions of private paratransit operation in Indonesia. J. Public Transp. 2007, 10, 99-118. [CrossRef]

39. Joewono, T.B.; Kubota, H. The Multigroup Analysis Regarding User Perception of Paratransit Service. In Proceedings of the 7th International Conference of Eastern Asia Society for Transportation Studies, Dalian, China, 24-27 September 2007; Volume 6. [CrossRef]

40. Tarigan, A.K.M.; Susilo, Y.O.; Joewono, T.B. Segmentation of paratransit users based on service quality and travel behaviour in Bandung, Indonesia. Transp. Plan. Technol. 2014, 37, 200-218. [CrossRef]

41. Phun, V.K.; Kato, H.; Yai, T. Traffic risk perception and behavioral intentions of paratransit users in Phnom Penh. Transp. Res. Part F Traffic Psychol. Behav. 2018, 55, 175-187. [CrossRef]

42. Tiglao, N.C.C.; De Veyra, J.M.; Tolentino, N.J.Y.; Tacderas, M.A.Y. The perception of service quality among paratransit users in Metro Manila using structural equations modelling (SEM) approach. Res. Transp. Econ. 2020, 83, 100955. [CrossRef]

43. Sharma, D.; Pandit, D.; Bose, T. Determination of service quality attributes based on user perception for paratransit services in developing country like India. Transp. Res. Procedia 2020, 48, 3577-3594. [CrossRef]

44. Nasrullah, N.; Suliyanto; Afif, N.C.; Kaukab, M.E. Exploring passengers' attitudes and loyalty in Jabodetabek: Paratransit during COVID-19 pandemic. Eur. J. Mol. Clin. Med. 2020, 7, 1618-1627.

45. Transportation Research Board. A Handbook for Measuring Customer Satisfaction and Service Quality; Transportation Research Board, United States Federal Transit Administration: Washington, DC, USA, 1999; Volume 47.

46. Oliver, R.L. Satisfaction: A Behavioral Perspective on the Consumer; McGraw-Hill Book Company: New York, NY, USA, 1997.

47. Allen, D.R. Customer Satisfaction Research Management: A Comprehensive Guide to Integrating Customer Loyalty and Satisfaction Metrics in the Management of Complex Organizations; ASQ Quality Press: Milwaukee, WI, USA, 2004.

48. Van Lierop, D.; El-Geneidy, A. Enjoying loyalty: The relationship between service quality, customer satisfaction, and behavioral intentions in public transit. Res. Transp. Econ. 2016, 59, 50-59. [CrossRef]

49. Zhao, J.; Webb, V.; Shah, P. Customer loyalty differences between captive and choice transit riders. Transp. Res. Rec. J. Transp. Board 2014, 2415, 80-88. [CrossRef]

50. Lai, W.; Chen, C. Behavioral intentions of public transit passengers: The roles of service quality, perceived value, satisfaction and involvement. Transp. Policy 2011, 18, 318-325. [CrossRef] 
51. Minser, J.; Webb, V. Quantifying the benefits: Application of customer loyalty modeling in public transportation context. Transp. Res. Rec. J. Transp. Res. Board 2010, 2144, 111-120. [CrossRef]

52. Dick, A.; Basu, K. Customer loyalty towards an integrated framework. J. Acad. Mark. Sci. 1994, 22, 99-113. [CrossRef]

53. Odin, Y.; Odin, N.; Valette-Florence, P. Conceptual and operational aspects of brand loyalty: An empirical investigation. J. Bus. Res. 2001, 53, 75-84. [CrossRef]

54. Jen, W.; Tu, R.; Lu, T. Managing passenger behavioral intention: An integrated framework for service quality, satisfaction, perceived value, and switching barriers. Transportation 2011, 38, 321-342. [CrossRef]

55. Imaz, A.; Habib, K.M.N.; Shalaby, A.; Idris, A.O. Investigating the factors affecting transit user loyalty. Public Transp. 2015, 7, 39-60. [CrossRef]

56. Tao, S.; Corcoran, J.; Mateo-Babiano, I. Modelling loyalty and behavioural change intentions of busway passengers: A case study of Brisbane, Australia. IATSS Res. 2017, 41, 113-122. [CrossRef]

57. Allen, J.; de Costa Rica, U.; Eboli, L.; Forciniti, C.; Mazzulla, G.; de Dios Ortúzar, J. The role of critical incidents and involvement in transit satisfaction and loyalty. Transp. Policy 2019, 75, 57-69. [CrossRef]

58. Timokhina, G.; Ivashkova, N.; Skorobogatykh, I.; Murtuzalieva, T.; Musatova, Z. Management of competitiveness of metropolis public transport in the COVID-19 pandemic based on core consumers' values. J. Open Innov. Technol. Mark. Complex. 2020, 6, 192. [CrossRef]

59. Sumaedi, S.; Bakti, I.G.M.Y.; Rakhmawati, T.; Astrini, N.J.; Widianti, T.; Yarmen, M. Factors influencing public transport passengers' satisfaction: A new model. Manag. Environ. Qual. 2016, 27, 585-597. [CrossRef]

60. Sun, S.; Xu, L.; Yao, Y.; Duan, Z. Investigating the determinants to retain spurious-loyalty passengers: A data-fusion based approach. Transp. Res. Part A Policy Pract. 2021, 152, 70-83. Available online: https://www.sciencedirect.com/science/article/ pii/S0965856421002032 (accessed on 20 October 2021). [CrossRef]

61. Nguyen-Phuoc, D.Q.; Oviedo-Trespalacios, O.; Vo, N.S.; Le, P.T.; Nguyen, T.V. How does perceived risk affect passenger satisfaction and loyalty towards ride-sourcing services? Transp. Res. Part D Transp. Environ. 2021, 97, 102921. [CrossRef]

62. Su, D.N.; Nguyen-Phuoc, D.Q.; Johnson, L.W. Effects of perceived safety, involvement and perceived service quality on loyalty intention among ride-sourcing passengers. Transportation 2021, 48, 369-393. [CrossRef]

63. Wenzel, T.; Rames, C.; Kontou, E.; Henao, A. Travel and energy implications of ridesourcing service in Austin, Texas. Transp. Res. Part D Transp. Environ. 2019, 70, 18-34. [CrossRef]

64. Yang, H.; Shao, C.; Wang, H.; Ye, J. Integrated reward scheme and surge pricing in a ridesourcing market. Transp. Res. Part B Methodol. 2020, 134, 126-142. [CrossRef]

65. Becker, H.; Balac, M.; Ciari, F.; Axhausen, K.W. Assessing the welfare impacts of shared mobility and mobility as a service (MaaS). Transp. Res. Part A Policy Pract. 2020, 131, 228-243. [CrossRef]

66. Narayan, J.; Cats, O.; Van Oort, N.; Hoogendoorn, S. Does ride-sourcing absorb the demand for car and public transport in Amsterdam? In Proceedings of the 6th International Conference on Models and Technologies for Intelligent Transportation Systems (MT-ITS) IEEE, Krakow, Poland, 5-7 June 2019; pp. 1-7.

67. Lehdonvirta, V.; Oksanen, A.; Räsänen, P.; Blank, G. Social media, web, and panel surveys: Using non-probability samples in social and policy research. Policy Internet 2021, 13, 134-155. [CrossRef]

68. Israel, G.D. Determining Sample Size. PEOD6, Agricultural Education and Communication Department, Florida Cooperative Extension Service, Institute of Food and Agricultural Sciences, University of Florida. 2012. Available online: http:/ / edis.ifas.ufl. edu (accessed on 23 June 2021).

69. MORPACE International, Inc.; Cambridge Systematics, Inc. A Handbook for Measuring Customer Satisfaction and Service Quality Focuses on How to Measure Customer Satisfaction and How to Develop Transit Agency Performance Measures; Transit Cooperative Research Program (TCRP) Report 47; Transportation Research Board, The National Academies of Sciences, Engineering, and Medicine: Washington, DC, USA, 1999.

70. Ausman, J.; Cleland, F.; Thompson, B. Transit Customer Satisfaction Index. Final Report; Center for Urban Transportation Research, University of South Florida: Tampa, FL, USA, 1999. Available online: https:/ / rosap.ntl.bts.gov/view/dot/49632 (accessed on 20 July 2021).

71. Sharma, D.; Pandit, D. Determining the level of service measures to evaluate service quality of fixed-route shared motorized para-transit services. Transp. Policy 2021, 100, 176-186. [CrossRef]

72. Fan, Y.; Chen, J.; Shirkey, G.; John, R.; Wu, S.R.; Park, H.; Shao, C. Applications of structural equation modeling (SEM) in ecological studies: An updated review. Ecol. Process. 2016, 5, 19. [CrossRef]

73. Dharmowijoyo, D.B.E.; Susilo, Y.O.; Karlström, A. On complexity and variability of individuals' discretionary activities. Transportation 2016, 45, 177-204. [CrossRef]

74. Kline, R.B. Principles and Practice of Structural Equation Modeling, 4th ed.; The Guilford Press: New York, NY, USA, 2016.

75. Hair, J.F.; Howard, M.C.; Nitzl, C. Assessing measurement model quality in PLS-SEM using confirmatory composite analysis. J. Bus. Res. 2020, 109, 101-110. [CrossRef]

76. Myung, I.J. Tutorial on maximum likelihood estimation. J. Math. Psychol. 2003, 47, 90-100. [CrossRef]

77. Gujarati, D. Basic Econometrics; McGraw Hill: Boston, MA, USA, 2003.

78. Hansen, C.B. Inference in Linear Panel Data Models with Serial Correlation and an Essay on the Impact of 401(k) Participation on the Wealth Distribution. Ph.D. Thesis, Massachusetts Institute of Technology, Cambridge, MA, USA, 2004. 
79. Mehta, P.D.; Neale, M.C. People are variables too: Multilevel structural equations modeling. Psychol. Methods 2005, 10, $259-284$. [CrossRef]

80. Hair, J.F.; Black, B.; Babin, B.J.; Anderson, R.E. Multivariate Data Analysis: International Edition, 7th ed.; Pearson: London, UK, 2013. Available online: https://www.pearson.com/uk/educators/higher-education-educators/program/Hair-Multivariate-DataAnalysis-Global-Edition-7th-Edition/PGM916641.html (accessed on 1 September 2021).

81. Wang, G.C.S.; Jain, C.L. Regression Analysis: Modeling E Forecasting; Institute of Business Forecasting: New York, NY, USA, 2003.

82. Edukasi Semut Angkot. Available online: https://pptik.itb.ac.id/?p=966 (accessed on 20 October 2021).

83. KIRI. Available online: https:/ / projectkiri.id/ (accessed on 20 October 2021).

84. Ndibatya, I.; Booysen, M.J. Minibus taxis in Kampala's paratransit system: Operations, economics and efficiency. J. Transp. Geogr. 2020, 88, 102853. [CrossRef]

85. Ndibatya, I.; Booysen, M.J. Characterizing the movement patterns of minibus taxis in Kampala's paratransit system. J. Transp. Geogr. 2021, 92, 103001. [CrossRef]

86. Tarabay, R.; Abou-Zeid, M. Modeling the choice to switch from traditional modes to ridesourcing services for social/recreational trips in Lebanon. Transportation 2020, 47, 1733-1763. [CrossRef]

87. Susilo, Y.O.; Santosa, W.; Joewono, T.B.; Parikesit, D. A reflection of motorization and public transport in Jakarta metropolitan area. IATSS Res. 2007, 31, 59-68. [CrossRef]

88. Ferris, B.; Kari, W.; Alan, B. OneBusAway: Results from Providing Real-Time Arrival Information for Public Transit. In Proceedings of the SIGCHI Conference on Human Factors in Computing Systems, Atlanta, GA, USA, 10-15 April 2010; ACM Press: Atlanta, GA, USA, 2010; pp. 1807-1816.

89. Mallat, N. Exploring consumer adoption of mobile payments: A qualitative study. J. Strateg. Inf. Syst. 2007, 16, 413-432. [CrossRef]

90. FitzRoy, F.; Smith, I. Season tickets and the demand for public transport. KYKLOS 1999, 52, 219-238. [CrossRef]

91. FitzRoy, F.; Smith, I. Public transport demand in Freiburg: Why did patronage double in a decade? Transp. Policy 1998, 5, 163-173. [CrossRef]

92. Matas, A. Demand and revenue implications of an integrated public transport policy: The case of Madrid. Transp. Rev. 2004, 24, 195-217. [CrossRef]

93. Redman, L.; Friman, M.; Gärling, T.; Hartig, T. Quality attributes of public transport that attract car users: A research review. Transp. Policy 2013, 25, 119-127. [CrossRef]

94. Ferreira, M.C.; Henriqueta, N.; Teresa, G.D.; João, F.C. A proposal for a public transport ticketing solution based on customers' mobile devices. Procedia Soc. Behav. Sci. 2013, 111, 232-241. [CrossRef]

95. Finzgar, L.; Trebar, M. Use of NFC and QR Code Identification in an Electronic Ticket System for Public Transport. In Proceedings of the 19th International Conference on Software, Telecommunications and Computer Networks, SoftCOM 2011, Split, Croatia, 15-17 September 2011; pp. 1-6.

96. Dziekan, K.; Arjan, V. Psychological effects of and design preferences for real-time information displays. J. Public Transp. 2006, 9 , 1. [CrossRef] 